\title{
PENGEMBANGAN MODUL PEMBELAJARAN BERBASIS MASALAH UNTUK MEMBANTU MENINGKATKAN BERFIKIR KREATIF MAHASISWA
}

\author{
Udin Erawanto $^{1)}$, Ekbal Santoso ${ }^{2)}$ \\ STKIP PGRI Blitar \\ Email: erawantoudin@yahoo.com \\ Email: ekbal.santoso@gmail.com
}

\begin{abstract}
ABSTRAK
Masalah penelitian adalah rendahnya kemampuan berfikir kreatif mahasiswa dalam menyelesaikan masalah. Tujuan penelitian menghasilkan modul pembelajaran berbasis masalah dapat membantu meningkatkan berfikir kreatif mahasiswa. Pengembangan modul menggunakan model 4D Thiagarajan dan Semmel, tetapi yang digunakan hanya 3D yaitu pendefinisian, perancangan, dan pengembangan. Untuk penyebaran tidak dilaksanakan karena tidak bertujuan melakukan generalisasi. Sasaran uji coba produk mahasiswa prodi PPKn STKIP PGRI Blitar angkatan 2014/2015. Perekaman data menggunakan lembar validasi, lembar observasi, tes penguasaan bahan ajar, dan angket respon mahasiswa. Analisis data menggunakan analisis deskriptif kualitatif dan analisis statistik deskriptif. Hasil penelitian: (1) berdasarkan kriteria yang telah ditetapkan semua instrumen memenuhi kevalidan (2) kepraktisan modul pada aspek keterlaksanaan modul mencapai skor $78.17 \%$ termasuk dalam kategori baik (3) aktivitas dosen dalam pembelajaran mencapai skor 83.06 termasuk dalam kategori aktif (4) Dilihat dari aspek keefektifan modul dengan indikator ketuntasan belajar mencapai skor $90.27 \%$ dikatakan tuntas, aktivitas mahasiswa mencapai skor 76.61\% masuk dalam kategori aktif. Respon mahasiswa atas penggunaan modul mencapai skor $1.66 \%$ memberi respon positif. Dengan mengacu pada indikator maka dapat disimpulkan bahwa modul PBL ini telah memenuhi syarat valid, praktis dan efektif.
\end{abstract}

Kata Kunci : Modul , Problem Based Learning, Berfikir Kreatif

\begin{abstract}
The problem of the research is the lack of creative thinking abilities from the students to solve problems. The purpose of this research is designing a module on problem-based learning models which increase the ability of creative thinking for the students. This module is developed by using 4D model from Thiagarajan and Semme, but only implemented the 3D model: defining, designing, and developing. The dessemination is not executed because the research does not aim to generalize the result. Targets of the product are students of PPKn major in STKIP PGRI BLITAR year 2014/2015. The instruments used to record the data are a validation sheets, observation sheets, test mastery of material, and students responses questionnairre. The data analysis is using descriptive analysis of qualitative and descriptive statistic statistical analysis. The result of the research depends on (1) a criteria which established that all the instruments are valid, (2) practically modules which implement aspect modules are achieving score $78.18 \%$ which categorized as good score, (3) lecturer activity in learning are achieving score $83.06 \%$ which categorized as active, (4) the module of affectiveness aspect is achieving accomplishment score $90.27 \%$ as a complete score. The students activity get the score $76.61 \%$ which categorized as active respons. Student responses by using this modules are scored $1.66 \%$ as positive response. By using these indicators, it can be concluded that PBL module are valid, practical, and effective.
\end{abstract}

Key words: Module, Problem Based Learning, Creative Thinking 


\section{PENDAHULUAN}

Pendidikan bertujuan menghasilkan sumber daya manusia yang berkualitas, sehingga mampu bersaing dengan tenaga kerja lain sesuai kompetensi yang dimilikinya dalam menghadapi persaingan global. Untuk itu perlu dibangun iklim pembelajaran berkualitas yang memberi kesempatan kepada pembelajar terlibat secara aktif dalam membangun konsep dan teori yang dipelajarinya. Dalam pembelajaran, dosen harus meninggalkan paradigma pembelajaran yang cenderung mekanik dan menoton, mengganti dengan paradigma pembelajaran konstruktivistik. Pembelajaran tidak lagi berpusat pada dosen melainkan pada mahasiswa. Dosen menciptakan iklim yang dapat membelajarkan mahasiswa, memberi kesempatan menggali, menemukan dan mengkontruk konsep dan materi yang dipelajari secara mandiri.

Hasil observasi peneliti terhadap sejumlah mahasiswa prodi PPKn STKIP PGRI Blitar yang menempuh matakuliah ilmu politik dihasilkan temuan sebagai berikut; kemampuan mahasiswa angkatan 2013/2014 yang mengikuti matakuliah ilmu politik sangat heterogen , ada yang cepat, sedang dan kurang dalam menerima materi hak asasi manusia. Mahasiswa lebih suka menghafal dari pada memahami makna materi perkuliahan. Mahasiswa mampu menguasai konsep tetapi lemah dalam penerapannya. Berfikir kreatif mahasiswa dalam menyelesaikan masalah sangat rendah, masih terjebak pola rutinitas dalam memberi jawaban. Bahan ajar kurang sesuai dengan kebutuhan dan karakteristik mahasiswa, kurang menggambarkan bahan ajar yang menghadapkan mahasiswa pada permasalahan yang akan diselesaikan dengan konsep atau materi yang hendak dipelajari. Sebagai akibatnya, mahasiswa sering mengalami kesulitan dalam menyelesaikan masalah.

Kondisi pembelajaran tersebut bila dibiarkan berdampak pada rendahnya kemampuan berfikir kreatif mahasiswa dalam menyelesaikan masalah.Akibat jangka panjang hasil belajar yang dicapai mahasiswa untuk mata kuliah ilmu politik dibawah standar ketuntasan belajar minimal. Upaya mengatasi masalah di atas dilakukan dengan meningkatkan keefektifan pembelajaran, dalam hal ini dosen menggunakan bahan ajar sesuai dengan kebutuhan dan karakteristik mahasiswa, salah satu bahan ajar yang dimaksud adalah modul. Modul pembelajaran selain memberi kesempatan belajar menurut cara dan kecepatan mahasiswa sendiri, juga memberi keleluasaan mahasiswa mengali informasi dan merumuskan pemecahan masalah dengan mengkaitkan pengetahuan yang dimiliki dengan kenyataan dalam kehidupan sehari-hari sehingga pembelajaran lebih bermakna.

Dalam penelitian ini dikembangkan modul pembelajaran berbasis masalah, merupakan salah satu model pembelajaran inovatif yang dapat mendorong mahasiswa terlibat secara aktif dalam memecahkan masalah sehingga dapat memahami materi yang dipelajari. Tujuan pengembangan ini untuk menghasilkan modul pembelajaran berbasis masalah yang dapat membantu mahasiswa berfikir kreatif dalam memahami materi hak asasi manusia pada mata kuliah ilmu politik. Modul dikatakan membantu bila memenuhi kriteria valid, praktis dan efektif. Aspek validitas diukur dari hasil validasi instrumen yang dilakukan oleh validator. Aspek kepraktisan diukur dari keterlaksanaan modul pada pembelajaran, mahasiswa aktif mengerjakan modul. Aspek keefektifan diukur dari ketuntasan 
belajar, aktivitas mahasiswa, dan respon mahasiswa terhadap modul.

Modul pembelajaran berbasis masalah ini dikembangkan dengan mengikuti model 4D yang dikemukakan Thiagarajan dan Semmel terdiri atas empat tahap yaitu tahap pendefinisian, tahap perancangan, tahap pengembangan, dan tahap penyebaran. Dalam penelitian ini yang diimplementasikan hanya 3D, untuk tahap penyebaran tidak dilakukan, karena penelitian ini tidak bertujuan untuk menggeneralisasikan hasil penelitian.

Komponen modul diadaptasi dari Degeng (2005:192) yang disesuaikan dengan sintaks PBL, meliputi: Pertama Pendahuluan; terdiri atas judul modul, kata pengantar, daftar isi, petunjuk pengelolaan pembelajaran dengan modul, petunjuk penggunaan modul untuk mahasiswa, deskripsi singkat materi, SK, KD, manfaat modul. Kedua isi, terdiri atas kegiatan belajar, indikator pembelajaran, tujuan pembelajaran, waktu penyajian, masalah pembuka, pengetahuan prasyarat, masalah dengan penyajian yang dapat membantu mahasiswa memahami materi, pemantapan. Ketiga bagian akhir, terdiri atas uji kompetensi, kunci jawab, umpan balik dan tindak lanjut.

Teori belajar yang mendasari pembelajaran berbasis masalah adalah teori konstruktivistik. Pengetahuan bukanlan sesuatu yang sudah jadi, melainkan sesuatu yang harus digali , ditemukan dan dibangun. Oleh karena itu diperlukan iklim pembelajaran yang dapat membelajarkan mahasiswa terlibat secara aktif dalam melakukan aktivitas belajar seperti berfikir kreatif dan kritis dalam menggali, menemukan dan membangun konsep dan materi yang dipelajari, termasuk dalam menyelesaikan masalah. Pembelajaran tidak lagi berpusat pada dosen melainkan pada mahasiswa. Dosen hanya berperan sebagai fasilitator, motivator dan dinamisator dalam kegiatan pembelajaran.

Hasil penelitian yang dilakukan Murdiono (2009) menghasilkan temuan bahwa penerapan strategi pembelajaran berbasis masalah dalam pembelajaran kewarganegaraan dapat meningkatkan partisipasi aktif mahasiswa dalam proses pembelajaran. Meningkatnya partisipasi aktif mahasiswa dalamproses pembelajaran menjadikan proses belajar mengajar dapat berlangsung secara efektif. Selain itu, metode ini dapat meningkatkan ketrampilan kewarganegaraan mahasiswa yang dimiliki mahasiswa. Hal ini dapat dilihat dari meningkatnya kemampuan melakukan analisis terhadap permasalahan yang telah diidentifikasi oleh masinng-masing kelompok. Suci (2008) hasil penelitianya mendapatkan temuan bahwa penerapan model pembelajaran berbasis masalah dengan pendekatan kooperatif dapat (1) meningkatkan aktivitas (partisipasi) mahasiswa dalam kegiatan belajar mengajar (2) mendapat respon yang positif dari mahasiswa karena pembelajaran menjadi lebih bermakna.

Sintak pembelajaran berbasis masalah dimulai dari: (1) penyajian masalah, dengan disajikan masalah yang kontekstual mahasiswa diminta memahami isi ceritanya; (2) mendiskusikan masalah; mahasiswa diminta mencari fakta-fakta dan merencanakan penyelesaian; (3) kembali pada kelompok; untuk mendiskusikan hasil kerjanya dan sharing dengan sesama teman; (4) belajar mandiri; diminta menduga jawaban, menguji jawaban, dan menyimpulkan hasil kerja; (5) mempresentasikan hasil diskusi (6) mereview hasil kerja.

Berfikir kreatif merupakan kompetensi yang harus dimiliki oleh mahasiswa.Berfikir 
kreatif menjadikan mahasiswa tidak lagi terjebak dalam rutinitas berfikir yang cenderung monoton dalam setiap menyelesaikan permasalahan. Mahasiswa dibiasakan berani keluar dari rutinitas berfikir dengan cara menumbuhkan keberaniannya berfikir divergen, yakni keberanian dalam menemukan dan menyampaikan gagasan-gagasan terbarunya dalam menyelesaikan permasalahan yang dihadapi. Mahasiswa dimotivasi lebih berani mengemukakan lebih dari satu solusi dalam menyelesaikan suatu permasalahan. Mahasiswa juga diberi kesempatan berani dan terbuka dalam melakukan telaah dan evaluasi terhadap kebijakan dan pendapat yang sudah ada. Hal ini dimaksudkan mahasiswa harus mampu melihat dan melakukan koreksi terhadap sesuatu hal secara objektif dan menyeluruh.

Berfikir kreatif mahasiswa dalam menyelesaikan masalah akan tumbuh dan berkembang jika didukung iklim pembelajaran yang mampu membelajarkan mahasiswa terlibat secara aktif dalam proses pembelajaran. Melalui modul pembelajaran berbasis masalah, mahasiswa dalam kegiatan pembelajaran dikondisikan terlibat secara aktif untuk memahami permasalahan yang telah disajikan, menggali fakta dan merencanakan penyelesaian, mendiskusikan hasil kerja dalam kelompok, belajar mandiri dengan melakukan kegiatan menduga, menguji jawaban dan menyimpulkan hasil kerja, mempresentasikan hasil kerja, dan melakukan review hasil kerja.

Dalam menyelesaikan masalah mahasiswa bersikap lebih dewasa dan bijaksana.Mahasiswa terlibat aktif memahami permasalahan, menggali dan menemukan fakta-fakta di lapangan, melakukan kerja kelompok dan kerja mandiri, keberanian mempresentasikan hasil kerja sebagai bentuk tanggungjawab keilmuan, bersikap terbuka atas masukan dan koreksi dari teman atas hasil kerjanya. Dengan model pembelajaran berbasis masalah ini mahasiswa dibiasakan keluar dari rutinitas berfikir.Mahasiswa diberi kesempatan secara terbuka menggali dan menemukan solusi terbaru dalam menyelesaikan masalah.Diberi kebebasan menemukan lebih dari satu solusi dan mengemukakan pemikiran terbarunya dalam menyelesaikan masalah tanpa takut salah.

Modul pembelajaran pada hakekatnya salah satu bentuk media cetak yang berisi satuan unit pembelajaran, dilengkapi dengan berbagai komponen (pendahuluan, isi dan akhir) sehingga memungkinkan mahasiswa dapat mencapai tujuan belajar secara mandiri atau dengan bantuan sekecil mungkin dari dosen, dan dapat mengevaluasi kemampuannya sendiri.

Peran dosen dalam pembelajaran modul terbatas memberi bantuan bila diperlukan mahasiswa atau bila melihat mahasiswa kesulitan dalam memahami materi dan menyelesaikan permasalah di modul. Menurut Warsono (2012:21) “tugas seorang fasilitator adalah: merencanakan pembelajaran, mengimplementasikan rancangan pembelajaran, menilai mahasiswa, dan melaksanakan evaluasi proses pembelajaran”.

Jadi pembelajaran dengan modul ini tidak berarti mahasiswa belajar terlepas dari bimbingan dan bantuan dosen sama sekali, melainkan masih dalam pengawasan, bimbingan dan bantuan dosen dalam mempelajari modul.

Modul pembelajaran yang dikembangkan adalah modul pembelajaran berbasis masalah disusun sesuai dengan kebutuhan dan karakteristik mahasiswa 
untuk mata kuliah ilmu politik pada materi HAM. Karakteristik pembelajaran berbasis masalah menurut Wena (2008:91) meliputi; (1) Belajar dimulai dari suatu permasalahan, (2) permasalahan yang diberikan harus berhubungan dengan dunia nyata siswa, (3) mengorganisasikan pembelajaran di sekitar permasalahan, (4) memberikan tanggung-jawab yang besar dalam membentuk dan menjelaskan secara langsung proses belajar mereka sendiri, (5) menggunakan kelompok kecil dan (6) menuntut siswa untuk mendemonstrasikan apa yang telah dipelajarinya dalam bentuk produk kerja.

Dari uraian di atas dapat dijelaskan bahwa model pembelajaran berbasis masalah dimulai dari masalah, kemudian mahasiswa memperdalam pengetahuannya tentang apa yang telah mereka ketahui dan apa yang mereka perlukan untuk memecahkan masalah tersebut. Masalah yang dijadikan fokus pembelajaran dapat diselesaikan mahasiswa melalui kerja kelompok sehingga dapat memberi pengalaman yang beragam.

Masalah yang diajukan merupakan masalah kontekstual dan tidak asing bagi mahasiswa. Sebagai contoh untuk memahami materi hak asasi manusia, mahasiswa dihadapkan pada konsep dasar hak asasi manusia, sejumlah contoh penerapan hak asasi manusia di bidang politik, ekonomi, sosio budaya, dan hukum, contoh kasus pelanggaran terhadap hak asasi manusia di bidang politik, ekonomi, sosio budaya dan hukum, beberapa contoh masalah yang rentan terhadap pelanggaran hak asasi manusia, upaya-upaya perlindungan terhadap hak asasi manusia. Melalui masalah yang diajukan mahasiswa dibantu untuk membangun pemahaman materi tersebut.

Pembelajaran berbasis masalah merupakan model pembelajaran yang mengacu pada teori pembelajaran konstruktivistik. Menurut pandangan konstruktivis, belajar merupakan proses pembentukan pengetahuan. Pengetahuan bukanlah sesuatu yang sudah ditentukan, melainkan sesuatu proses pembentukan. Pembentukan ini harus dilakukan oleh mahasiswa dalam proses pembelajaran. Mahasiswa harus aktif melakukan kegiatan, aktif berfikir, menyusun konsep dan materi serta memberi makna tentang hal yang dipelajari.

Sudut pandang konstruktivis pengembangan modul ini akan bersandarkan kepada konstrukstivis model BIG. Konstruktivis model BIG memiliki karakteristik sebagai berikut ; (1) pengajar menyediakan informasi yang lengkap, dan (2) pebelajar dituntut untuk mampu bergerak melebihi informasi yang diberikan. Maksudnya, pebelajar "berkutat" tidak hanya kepada informasi yang tertulis, tetapi melalui aktivitas mental dia harus memaknai informasi itu, membangun persepsi, menginvestigasi kemungkinan saling ke-terkaitan yang ada, dan sebagainya. Singkatnya mereka dituntut menginvestigasi secara mendalam (indepth investigation) informasi yang diterima.

Dariyo (2004:71) mengemukakan berfikir kreatif disebut pula sebagai berpikir divergen. Berfikir kreatif adalah cara berfikir yang bersifat baru, unik, tidak seperti biasanya, atau lain dari yang lain. Orang yang berfikir kreatif berani mempertahankan pemikiran atau pendiriannya dan berani pula untuk mengambil resiko untuk ditentang, ditolak, atau dicaci maki oleh lingkungan sosialnya. Selain itu, orang yang berfikir kreatif adalah orang yang mampu melaksanakan pemikiran-pemikiran kreatif ke dalam bentuk karya yang baru, unik dan berbeda dari yang lainnya. Jadi pemikir kreatif 
harus mau bersusah payah, bertindak dan melakukan aktivitas untuk mengejawantahkan pemikirannya sungguhsungguh sehingga berhasil baik.

Berfikir kreatif merupakan kompetensi yang harus dimiliki oleh mahasiswa. Berfikir kreatif menjadikan mahasiswa tidak lagi terjebak dalam rutinitas berfikir yang cenderung monoton dalam setiap menyelesaikan permasalahan. Mahasiswa dibiasakan berani keluar dari rutinitas berfikir dengan cara menumbuhkan keberaniannya berfikir divergen, yakni keberanian dalam menemukan dan menyampaikan gagasan-gagasan terbarunya dalam menyelesaikan permasalahan yang dihadapi. Mahasiswa dimotivasi lebih berani mengemukakan lebih dari satu solusi dalam menyelesaikan suatu permasalahan. Mahasiswa juga diberi kesempatan berani dan terbuka dalam melakukan telaah dan evaluasi terhadap kebijakan dan pendapat yang sudah ada. Hal ini dimaksudkan mahasiswa harus mampu melihat dan melakukan koreksi terhadap sesuatu hal secara objektif dan menyeluruh.

Kemampuan berfikir kreatif mahasiswa akan muncul dan berkembang bilamana didukung iklim pembelajaran yang baik. Kegiatan pembelajaran terpusat pada mahasiswa, dosen hanya sebagai fasilitator, motivator dan dinamisator. Strategi pembelajaran tidak lagi menganut pola pembelajaran konvensional, melainkan sudah mengacu dan menerapkan model pembelajaran konstruktivistik. Dalam paradigma konstruktivistik, pengetahuan itu bukanlah sesuatu yang sudah jadi melainkan harus dibangun. Oleh karena itu kegiatan pembelajaran harus menyediakan bahan ajar yaitu modul pembelajaran berbasis masalah, yang memerlukan keterlibatan mahasiswa secara aktif dalam pembelajaran. Dalam kegiatan pembelajaran mahasiswa dihadapkan pada permasalahan kontekstual. Berbekal pengalaman yang dimiliki mahasiswa diberi kesempatan mencari dan menemukan beberapa alternatif jawaban untuk menyelesaikan permasalahan yang dihadapi. Mahasiswa diminta menemukan sejumlah fakta-fakta, menduga dan menguji jawaban, menyelesaikan masalah baik melalui kerja mandiri dan kerja kelompok, memperesentasikan hasil kerja dan melakukan review hasil kerjanya. Dengan demikian mahasiswa akan terlepas dari pola rutinitas jawaban dalam menyelesaiakan masalah yang dihadapi.

\section{METODE}

Model penelitian ini adalah penelitian pengembangan. Penelitian ini bertujuan menghasilkan modul pembelajaran berbasis masalah yang dapat membantu meningkatkan berfikir kreatif mahasiswa pada mata kuliah ilmu politik untuk materi hak asasi manusia.

Model pengembangan yang digunakan adalah model 4D (four D model) oleh Thiagarajan dan Semmel (1974). Tahap pengembangan menurut model ini ada empat tahap, yaitu tahap pendefinisian (define), perancangan (design), pengembangan (develop), dan penyebaran (disseminate). Dalam penelitian ini, ada beberapa penyesuaian yang perlu dilakukan, karena penelitian ini tidak bertujuan untuk membuat generalisasi sehingga proses pengembangan lebih sesuai dengan kondisi subyek penelitian, adapun penyesuaiannya tahap penyebaran tidak dilakukan.

Subjek uji coba modul hasil pengembangan adalah mahasiswa prodi PPKn STKIP PGRI Blitar tahun akademik 2014/2015. Jumlah 24 
mahasiswa dengan perincian 6 laki-laki dan 18 perempuan. Data yang diperoleh dari uji coba produk pengembangan berupa data kuantitatif dan kualitatif. Data kuantitatif berupa skor yang diperoleh melalui lembar validasi, lembar observasi, angket respon mahasiswa, TPBA. Sedangkan data kualitatif berupa catatan, saran atau komentar berdasarkan hasil penilaian ahli.

Instrumen penelitian menggunakan lembar validasi digunakan untuk memvalidasi kevalidan modul, RPP, dan semua instrumen yang dipakai uji coba. Lembar observasi digunakan untuk mengamati keterlaksanaan modul, aktivitas dosen dan mahasiswa. Untuk mengetahui tingkat keefektifan modul digunakan lembar observasi aktivitas mahasiswa, tes penguasaan bahan ajar dan angket respon mahasiswa.

Analisis data yang digunakan pada penelitian ini adalah analisis deskriptif kualitatif dan analisis statistik deskriptif. Analisis deskriptif kualitatif digunakan untuk menganalisis data berupa catatan, saran, atau komentar berdasarkan hasil penilaian yang terdapat pada lembar validasi, lembar observasi, dan angket mahasiswa. Analisis statistik deskriptif digunakan untuk menganalisis data berupa skor hasil validasi, observasi, angket respon mahasiswa dan tes hasil belajar.

\section{HASIL DAN PEMBAHASAN}

Dari hasil kajian awal dihasilkan temuan bahwa bahan ajar selama ini yang digunakan dalam pembelajaran kurang sesuai dengan kebutuhan dan karakteristik mahasiswa, kurang dapat menumbuhkan dan mengembangkan kemampuan berfikir kreatif mahasiswa sehingga mahasiswa sering mengalami kesulitan dalam menyelesaikan masalah. Disamping itu proses pembelajaran masih makanik dan monoton, situasi pembelajaran masih didominasi dosen, dalam pembelajaran pengetahuan yang disampaikan sangat prosedural.

Terjadinya pergeseran paradigma pembelajaran dari behavioristik ke konstruktivistik memberikan dampak dalam proses pembelajaran. Pembelajaran tidak lagi terpusat pada dosen melainkan pada mahasiswa. Dosen berperan sebagai motivator,fasilitator dan dinamistor dalam pembelajaran. Sedangkan mahasiswa diberi kesempatan terlibat secara aktif, berfikir secara kritis, kreatif dan inovatif dalam menggali, menemukan dan membangun pengetahuan yang dipelajari.

Modul pembelajaran berbasis masalah yang dapat membantu meningkatkan berfikir kreatif mahasiswa prodi PPKn disusun untuk menyediakan bahan ajar yang sesuai dengan kebutuhan dan karakteristik mahasiswa. Pembelajaran berbasis masalah ini merupakan salah satu bentuk strategi pembelajaran yang mengacu pada pendekatan konstruktivistik. Pembelajaran melalui pemecahan masalah diawali dengan penyajian masalah-masalah yang diambil dari lingkungan sekitar mahasiswa sesuai dengan materi yang diajarkan. Masalah yang disajikan adalah masalah kontekstual yaitu masalah yang semestinya dapat dipecahkan mahasiswa sesuai dengan pengalaman mahasiswa dalam kehidupannya.

Prototipe yang dihasilkan dalam tahap perancangan terdiri atas : Modul, Rencana Pelaksanaan Perkuliahan, tes penguasaan bahan ajar, instrumen penelitian, lembar validasi. Setelah disusun semua prototipe selanjutnya divalidasi. Saran dari validator digunakan untuk melakukan menyempurnakan modul.

Tahap pengembangan meliputi; Validasi untuk mengetahui tingkat 
kevalidan instrumen yang dikembangkan dan melakukan uji coba untuk mengetahui tingkat kepraktisan dan keefektifan modul dalam pembelajaran. Hasil validasi dari modul dengan skor rata-rata seluruh aspek adalah 2,55, RPP skor rata-rata seluruh aspek adalah 2,72, lembar observasi keterlaksanaan modul dengan skor rata-rata seluruh aspek adalah 2,48, lembar observasi aktifitas dosen skor ratarata seluruh aspek adalah 2,76, tes penguasaan bahan ajar dengan rata-rata skor seluruh aspek adalah 2,72, angket respon mahasiswa dengan skor rata-rata seluruh aspek adalah 2,73. Berdasarkan kriteria yang telah ditetapkan semua instrumen memenuhi kevalidan.

Pada tahap berikutnya dilakukan uji coba lapangan dengan melibatkan 2 (dua) observer yaitu teman sejawat untuk mengamati keterlaksanaan modul, aktivitas dosen dan mahasiswa dalam pembelajaran. Uji coba ini bertujuan untuk mengetahui tingkat kepraktisan dan keefektifan modul yang dihasilkan.

Kepraktisan modul dengan aspek keterlaksanaan modul dihasilkan skor rata-rata keterlaksanaan seluruh sintaks PBL adalah $78.17 \%$ masuk dengan kategori baik. Aktivitas dosen dalam pembelajaran dengan menerapkan strategi pembelajaran berbasis masalah dihasilkan skor 83.06\% masuk dalam kategori aktif. Aktivitas dosen sebagai salah satu indikator kepraktisan modul, mengingat sebagus dan sebaik apapun modul itu disusun kalau tidak dapat dimplementasikan dengan baik dalam kegiatan pembelajaran maka modul tersebut dikatakan tidak praktis. Dari hasil observasi nampak bahwa dosen pengampu mata kuliah ilmu politik dalam menjelaskan materi HAM telah mampu melaksanakan sintaks PBL dengan baik sehingga modul yang dikembangkan ini memenuhi aspek kepraktisan.

Dilihat dari aspek keefektifan modul dengan indikator ketuntasan belajar mencapai 90.27\%, secara klasikal kelas uji coba dikatakan tuntas, aktivitas mahasiswa mencapai skor $76.61 \%$ masuk dalam kategori aktif. Sedangkan respon mahasiswa atas penggunaan bahan ajar berupa modul pembelajaran berbasis masalah ini mencapi skor 1,66 , berarti secara keseluruhan mahasiswa memberi respon positif. Dengan mengacu pada indikator tersebut dapat disimpulkan bahwa modul PBL ini telah memenuhi syarat keefektifan.

Modul pembelajaran berbasis masalah hasil pengembangan ini terdiri atas 3 (tiga) kegiatan pembelajaran, dimana masingmasing kegiatan belajar memuat komponen penting yang berbeda dengan bahan ajar lainnya.Kegiatan belajar 1 memuat materi konsep dasar hak asasi manusia. Kegiatan belajar 2 memuat materi tentang kasuskasus pelanggaran terhadap hak asasi manusia. Kegiatan belajar 3 memuat materi tentang penegakan hak asasi manusia. Bagian akhir modul disertai glosarium bertujuan membantu mahasiswa memahami istilah-istilah baru yang ada dalam modul yang dikembangkan.

Karakteristik modul yang dikembangkan ini berbasis masalah, sehingga setiap awal kegiatan pembelajaran selalu diawali dengan penyajian masalah, selanjutnya mahasiswa diminta beraktivitas dengan melakukan tahapan kegiatan sebagai berikut:

1. Penyajian masalah; dengan disajikan masalah yang kontekstual mahasiswa diminta memahami isi ceritanya. Kemudian dipandu mencari dan menuliskan informasi kunci dari cerita yang disajikan, sebagai dasar 
membuat rancangan penyelesaian berikutnya. Dari hasil observasi selama berlangsung pembelajaran dengan menggunakan modul secara keseluruhan aktivitas mahasiswa pada tahap ini mencapai skor $78.17 \%$ dengan kategori baik.

2. Mendiskusikan masalah; mahasiswa diminta mencari fakta-fakta dan merencanakan penyelesaian. Syarat utama supaya dapat menemukan fakta harus memahami dan menemukan isi cerita dari masalah yang disajikan. Secara keseluruhan skor yang dicapai pada tahap ini $75 \%$ sehingga termasuk dalam kategori baik. Untuk tahap perencanaan penyelesaian masalah, mahasiwa diberi tugas merumuskan dan menemukan penyelesaian masalah. Dari hasil observasi selama 3 (tiga) kali kegiatan pembelajaran mencapai skor $77.78 \%$, artinya mahasiswa sudah mampu melakukan aktivitas ini dengan baik. Untuk kegitan diskusi secara keseluruhan mencapai skor rata-rata $77.78 \%$, artinya mahasiswa dapat melakukan aktivitas diskusi dengan baik, mengingat mahasiswa sudah memahami inti permasalahannya.

3. Belajar mandiri; mahasiswa diminta menduga jawaban, menguji jawaban, dan menyimpulkan hasil kerja. Pada tahap menduga jawaban, mahasiswa membuat dugaan atas jawaban permasalahan.Awalnya terdapat beberapa mahasiswa merasa kesulitan dalam menduga jawaban, sehingga masih perlu untuk dipandu. Aktivitas mahasiswa pada tahap ini secara keseluruhan mencapai $77.78 \%$, masuk dalam kategori baik. Tahap berikutnya menguji jawaban; pada awalnya mahasiswa masih perlu bimbingan dan pengarahan dari dosen, mengingat pola pembelajaran ini pertama kali diperkenalkan dan diuji cobakan. Secara keseluruhan pada tahap ini mencapai skor $77.78 \%$ dengan kategori baik. Pada tahap menyimpulkan hasil kerja; mahasiswa dipandu membuat kesimpulan dari hasil kerja. Secara keseluruhan diperoleh skor 72.22\% dalam kategori baik.

Sebelumnya dosen menjelaskan maksud belajar mandiri adalah mahasiswa tetap duduk berkelompok tetapi mengerjakan tugas secara sendiri-sendiri.Setelah tugas mandiri selesai dikerjakan, berikutnya diminta kerja secara kelompok. Dari hasil pengamatan selama berlangsung kegiatan belajar 3 kali diperoleh skor rata-rata $75.93 \%$ dengan kategori baik.

4. Kembali pada kelompok; aktivitas yang dilakukan mahasiswa kembali pada kelompoknya untuk mendiskusikan hasil kerjanya dan sharing dengan sesama teman. Secara keseluruhan pada fase kegiatan ini menunjukkan skor $77.78 \%$ sesuai dengan kriteria yang ditetapkan yaitu masuk kategori baik.

5. Mempresentasikan hasil diskusi; mahasiswa yang memahami materi tidak merasa kesulitan dalam menyajikan atau menyampaikan hasil pekerjaan dengan bahasanya sendiri. Pada fase ini dicapai skor $76,67 \%$ dan sesuai dengan criteria yang ditetapkan masuk kategori baik.

6. Mereview hasil hasil kerja; mahasiswa yang memahami meteri berusaha melihat kembali, mengecek dan menelaah ulang hasil pekerjaannya. Pada fase ini dicapai skor $72.22 \%$ dan sesuai dengan criteria yang ditetapkan masuk dalam kategori baik. 


\section{SIMPULAN}

Modul pembelajaran berbasis masalah yang dapat membantu meningkatkan berfikir kreatif mahasiswa pada mata kuliah ilmu politik untuk materi HAM disusun sesuai karakteristik dan kebutuhan mahasiswa, dikembangkan dengan menggunakan model 4D Thiagarajan dan Semmel terdiri atas empat tahap, tetapi yang digunakan hanya 3D yaitu pendefinisian, perancangan, dan pengembangan. Untuk penyebaran tidak dilaksanakan karena tidak bertujuan melakukan generalisasi. Berdasarkan hasil validasi dan uji coba lapangan terhadap modul, RPP, dan instrumen, semua aspek mencapai kriteria yang ditetapkan. Modul pembelajaran berbasis masalah ini telah memenuhi kriteria valid, praktis dan efektif.

Kelemahan dari pelaksanaan modul pembelajaran berbasis masalah ini sebagai berikut: (1) model pembelajaran ini membutuhkan waktu cukup lama, sehingga perlu memperhatikan waktu saat berlangsung pembelajaran. Konsistensi penggunaan alokasi waktu harus tetap terjaga sesuai perencanaan awal. (2) Bagi mahasiswa yang berkemampuan dan berkemauan rendah, dengan mengunakan model pembelajaran berbasis masalah ini akan mendapat pengalaman belajar kurang menyenangkan. (3) Dalam pelaksanaan uji coba modul hasil pengembangan ini, mahasiswa bisa membawanya dan mengerjakanya, baik dikampus maupun dirumah. Tidak menutup kemungkinan mahasiswa mempelajari materi HAM dari sumber lain, sehingga mahasiswa tidak semata-mata belajar dari modul ini saja melainkan juga mencari dari sumber lain.

\section{DAFTAR PUSTAKA}

Dariyo, Agoes,2004. Psikologi Perkembangan Remaja, Bogor, Ghalia Indonesia

Degeng, I Nyoman S, 2005. Teori Pembelajaran II, Malang: Universitas Kanjuruhan Malang

Murdiono, Mukhammad. Peningkatan Ketrampilan Kewarganegaraan (Civic Skills) Melalui Penerapan Strategi Pembelajaran Berbasis Masalah (Problem Based Learning), http:// staff.uny.ac.id/ sites/default/ files/ 132304487/B3, diakses tanggal 7 April 2014

Suci, Ni Made.2008.Penerapan Model Problem Based Learning Untuk Meningkatkan Partisipasi Belajar dan Hasil Belajar Teori Akuntansi Mahasiswa Jurusan Ekonomi Undiksa, JPPP-2(1), 74-86, Lembaga Penelitian Undiksa, April 2008, Diakses tanggal 7 April 2014

Thiagarajan,S. Semmel,DS, \&Semmel, M.I.1974.Instructional Development for Training Teacher of Exceptional Children. Minnepolis,Minnesota; Leadership trainin special education, University of Minnesota

Warsono \& Hariyanto. 2012. Pembelajaran Aktif Teori dan Asesmen. Bandung: Rosda

Wena, Made. 2008. Strategi Pembelajaran Inovatif Kontemporer Suatu Tinjauan Konseptual Operasional, Jakarta: Bumi Aksara 